\title{
Sources of Illustrations
}

Figures 4.1 and 4.2 from The Young Lions (1958), dir. Edward Dmytryk (DVD: Warner Bros, 2004)

Figure 4.3 from I Confess (1953), dir. Alfred Hitchcock (DVD: Twentieth Century Fox, 2005)

Figure 4.4 Tom Batchell, illustration for The New Yorker, 5 January 2009 , used by permission of the artist

Figures 4.5 and 4.6 from Valkyrie (2008), dir. Bryan Singer (DVD: Twentieth Century Fox, 2009)

Figures 5.1 and 5.7 to 5.11 from Inglourious Basterds (2009), dir. Quentin Tarantino (DVD: Universal Studios, 2009)

Figures 5.2 and 5.3 from Schtonk! (1993), dir. Helmut Dietl (DVD: Eurovideo, n.d.)

Figures 5.4 and 5.6 from The Producers (1968), dir. Mel Brooks (DVD: Momentum Pictures, 2004)

Figure 5.5 Members of the Hitler Youth parade in the formation of a swastika in honour of the Unknown Soldier, Germany, 27 August 1933, used by permission of The Associated Press 